\title{
Pengembangan Modul Biologi Metode POE (Predict, Observe, Explain) disertai Nilai Karakter Materi Sistem Respirasi
}

\author{
Ni Nyoman Ernita Dewi ${ }^{1)}$, Handoko Santoso ${ }^{2)}$, Agil Lepiyanto ${ }^{3)}$ \\ ${ }^{122) 3)}$ Pendidikan Biologi, Fakultas Keguruan dan Ilmu Pendidikan, Universitas Muhammadiyah Metro \\ E-mail:ninyomanernitadewi112@gmail.com ${ }^{1)}$ \\ E-mail :handoko.umm@gmail.com²) \\ E-mail:lepi22evolusi@gmail.com ${ }^{3)}$
}

APA Citation: Dewi, N, N, E., Santoso, H., \& Lepiyanto, A. (2020). Pengembangan Modul Biologi Metode POE (Predict, Observe, Explain) disertai Nilai Karakter Materi Sistem Respirasi, Quagga: Jurnal Pendidikan dan Biologi, 12(2), 211-217, doi: 10.25134/quagga.v12i2.2898.

Received: 10-05-2020

Accepted: 24-06-2020

Published: 01-07-2020

Abstrak: Tujuan dari penelitian ini yaitu menghasilkan modul sistem respirasi dengan metode POE (Predict, Observe, Explain) disertai nilai karakter jujur, disiplin, peduli lingkungan, dan rasa ingin tahu. Penambahan nilai karakter pada modul bertujuan menjadikan peserta didik sebagai generasi yang memiliki karakter baik untuk menghadapi dinamika perubahan di masa depan. Penambahan Metode POE (Predict Observe Explain) juga memiliki kelebihan yaitu peserta didik mampu berpikir kreatif untuk mengemukakan prediksi terhadap suatu permasalahan yang muncul dan memacu peserta didik untuk membuktikan prediksinya dengan upaya penyelidikannya dan mendukung ilmu pengetahuan yang dipelajarinya. Jenis penelitian ini menggunakan metode Research and Development, model 4-D, sampai tahapan develop. Validasi modul dilakukan oleh para ahli dan telah direvisi. Uji coba dilakukan pada kelas kecil dengan 20 peserta didik. Aspek penilaian modul oleh pakar terdiri atas ahli desain dan ahli materi, dengan menggunakan instrumen angket. Hasil menunjukkan nilai dari ahli desain 86\% dan ahli materi 90\%. Instrumen untuk mengetahui kelayakan dan keterbacaan modul menggunakan angket yang diisi oleh peserta dengan nilai 86\%. Berdasarkan validasi ahli dan uji coba menunjukkan bahwa modul ini memenuhi kriteria kelayakan dan keterbacaan sangat baik.

Kata kunci: Modul metode POE (Predict, Observe, Explain); nilai karakter.

Abstract: The purpose of this study is to produce a respiration system module using the POE (Predict, Observe, Explain) method with honest character values, discipline, care for the environment, and curiosity. The addition of character values in the module aims to make students a generation that has good character to face the dynamics of change in the future. The addition of the POE (Predict Observe Explain) Method also has the advantage that students are able to think creatively to make predictions about a problem that arises and encourage students to prove their predictions with an effort to investigate and support the knowledge learned. This type of research uses the Research and Development method, 4-D model, until the develop stage. Module validation was carried out by experts and has been revised. The trial was conducted in a small class with 20 students. The aspects of module assessment by experts consist of design experts and material experts, using a questionnaire instrument. The results showed the value of design experts was $86 \%$ and material experts were $90 \%$. The instrument to determine the feasibility and readability of the module uses a questionnaire filled in by participants = with a value of $86 \%$. Based on expert validation and trials it shows that this module meets the eligibility and readability criteria very well.

Keywords: Module POE method (Predict, Observe, Explain); character value.

\section{PENDAHULUAN}

Kegiatan pembelajaran di sekolah memerlukan bahan ajar yang memadai. Bahan ajar adalah bagian yang penting dari suatu proses pembelajaran yang memuat materi atau isi pembelajaran dan mendukung kegiatan pembelajaran (Ramdani,2012).

Berdasarkan hasil observasi dapat diketahui bahwa di SMA PGRI Seputih Raman menggunakan kurikulum 2013, sehingga dalam proses pembelajaran perlu menerapkan strategi peserta didik aktif, interaktif, dan inspiratif (Richardo,2016). Kondisi tersebut tentu berlaku juga pada proses pembelajaran biologi. Guru dituntut perlu kreatif dan inovatif menggunakan berbagai macam metode pembelajaran untuk 
menyampaikan materi-materi pada mata pelajaran biologi.

Akan tetapi, pembelajaran peserta didik belum sepenuhnya diterapkan oleh guru biologi di SMA PGRI Seputih Raman. Sebagai contoh, pembelajaran materi sistem respirasi menggunakan metode yang variatif sehingga siswa menjadi kurang aktif. Guru juga belum membekalkan karakter jujur, disiplin, rasa ingin tahu, dan peduli lingkungan. Guru masih menggunakan modul pembelajaran yang tradisional, belum melatihkan kemampuan investigasi ilmiah.

Saat ini dibutuhkan metode pembelajaran yang terintegrasi di dalam bahan ajar/modul yang dapat membantu peserta didik untuk lebih aktif dalam pembelajaran. Salah satu caranya, yaitu dengan mengembangkan bahan ajar yang menggunakan metode pembelajaran POE (Predict, Observe, Explain) yang terintegrasi dengan mengembangkan karakter. Dengan adanya modul ini diharapkan membekalkan.

Metode pembelajaran POE (Predict Observe Explain) dapat mengembangkan keterampilan peserta didik dengan melalui kegiatan observasi, melatih kemampuan peserta didik untuk dapat membuat prediksi atau dugaan terhadap pengamatan yang akan dilakukan ( $\underline{\text { Ayu }}$ dan Lepiyanto, 2019). Metode POE (Predict Observe Explain) memiliki kelebihan yaitu peserta didik mampu berpikir kreatif untuk mengemukaan prediksi terhadap suatu permasalahan yang muncul dan memacu peserta didik untuk membuktikan prediksinya dengan upaya penyelidikannya dan mendukung ilmu pengetahuan yang dipelajarinya.

Berdasarkan penjelasan tersebut, diketahui bahwa metode POE (Predict, Observe, Explain) merupakan serangkaian proses pemecahan masalah dengan melakukan predict atau dugaan terhadap pengamatan yang akan dilakukan, pada kegiatan observe atau observasi juga dapat melatih keterampilan peserta didik, dan menyampaikan pendapat pada tahap explain (Widyaningrum,2013).

Berdasarkan penjelasan tersebut, tujuan penelitian ini adalah menghasilkan modul pembelajaran biologi dengan metode POE (Predict Observe Explain) disertai nilai karakter pada materi sistem respirasi yang layak berdasarkan pendapat pakar dan hasil uji coba terbatas. Penyusunan modul ini diharapkan mampu membantu tercapainya tujuan pembelajaran, dari kegiatan pada metode POE (Predict Observe Explain) peserta didik mampu lebih aktif, dan kreatif dalam pembelajaran selain kognitif nya yang terasah, nilai karakter dapat berkembang dengan baik, melalui pengembangan nilai karakter.

\section{METODOLOGI PENELITIAN}

Validasi modul topik respirasi yang menggunakan metode POE (Predict, Observe, Explain) dilakukan oleh para ahli yang terdiri atas ahli desain dan ahli materi. Validasi dari ahli desain dilakukan oleh 2 orang pakar dari LPTK dan 1 guru biologi. Validasi materi dilakukan oleh 2 pakar dari LPTK dan 1 guru biologi. Modul diujicobakan pada kelompok kecil yang terdiri atas 8 peserta didik SMA yang ditentukan secara acak.

Kajian pengembangan modul ini menggunakan data kualitatif dan data kuantitatif. Data kualitatif berupa data yangbersifat deskriptif yang diperoleh melalui angket dari kritik dan saran para ahli. Adapun data kuantitatif ini berupa angka-angka hasil penilaian modul melalui angket yang telah dinilai oleh validator ahli desain, ahli materi, dan uji coba kelompok kecil. Analisis data dengan cara menghitung hasil persentase jawaban angket dari setiap percoban sesuai dengan pernyataan oleh Herdianawati, Fitrihidajati dan Purnomo (2013:100), sebagai berikut:

Nilai $=\frac{\text { Rata-rata skor validasi }}{\text { Jumlah skor maksimal }}$ X 100\%

\section{HASIL DAN PEMBAHASAN}

Data kuantitatif menyajikan hasil penilaian modul melalui angket yang telah dinilai oleh validator ahli desain dengan peresentase $86 \%$, validasi ahli materi sebesar $90 \%$, dan uji coba kelompok kecil sebesar 86\%. Hasil analisis data tersebut dapat dilihat pada Gambar 1.

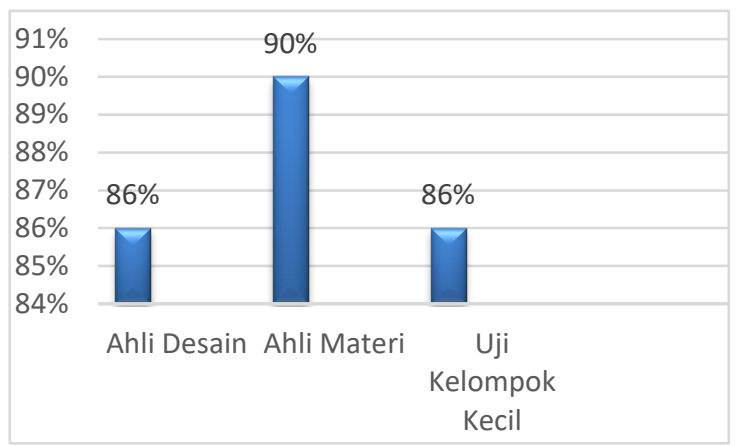

Gambar 1. Diagram Batang Hasil Validasi dan Uji Coba Kelompok Kecil. 
Berdasarkan Gambar 1. diperoleh skor yang didapatkan dari hasil validasi ahli desain, ahli materi, dan uji kelompok kecil dengan presentase $81 \%-100 \%$. Menurut Riduwan dan Akdon (2015) presentase $81 \%-100 \%$ dengan katagori sangat baik, sehingga modul telah layak untuk digunakan dalam pembelajaran.

Produk yang dihasilkan yaitu berupa modul metode POE (Predict, Observe, Explain) disertai dengan nilai karakter pada materi sistem respirasi. Menurut Nugraha (2019) bahwa metode POE (Predict, Observe, Explain) dapat meningkatkan pemahaman pada peserta didik. Metode pembelajaran ini melatih peserta didik berpikir kritis, dan kreatif dengan melakukan prediksi atau dugaan terhadap pengamatan yang dilakukan. Menurut Megayani (2017) bahwa metode POE (Predict, Observe, Explain) terdiri atas 3 komponen atau tahapan yaitu prediksi (predict), observasi (observe), dan eksplanasi (explain). Komponen atau tahapan prediksi (predict) yaitu suatu proses kegiatan peserta didik membuat dugaan tentang suatu kegiatan yang ditampilkan di dalam modul. Komponen atau tahapan observasi (observe) yaitu suatu kegiatan peserta didik melakukan percobaan untuk membuktikan kebenaran dari prediksi yang telah dilakukan, dan komponen atau tahapan yaitu eksplanasi (explain) merupakan suatu kegiatan peserta didik memberikan penjelasan mengenai kesesuaian antara dugaan dengan hasil observasi. Menurut Ariyanti (2018) bahwa metode POE (Predict, Observe, Explain) cocok diterapkan dalam meningkatkan ketertarikan peserta didik, yang berhubungan dengan pembelajaran sains, selain metode POE (Predict, Observe, Explain), modul ini juga disertai dengan nilai-nilai karakter.

Nilai karakter tersebut yaitu nilai karakter peduli lingkungan, dan rasa ingin tahu terdapat pada gambar-gambar yang berisi narasi pada modul, dan nilai karakter jujur dan disiplin dalam modul yang diharapkan mampu menumbuhkan nilai karakter pada peserta didik. Menurut Sayektiningsih (2017) bahwa penanaman nilai karakter dapat dilakukan secara intensif dikembangkan untuk menghasilkan generasi yang berakhlak. Nilai karakter perlu ditanamkan pada diri peserta didik, berharap bangsa Indonesia menjadi bangsa yang bermartabat, dan masyarakatnya mempunyai nilai tambah serta dapat bersaing dengan bangsa yang lain. Menurut Hidayah (2015) bahwa karakter dibentuk dan dikembangkan melalui pendidikan nilai. Nilai karakter ditambahkan dalam modul pembelajaran biologi ini karena kurikulum 2013 sebagai sebuah rujukan proses kegiatan pembelajaran pada satuan pendidikan, perlu mengintegrasikan Penguatan Pendidikan Karakter (PPK). Berdasarkan Peraturan Presiden Nomor 87 tahun 2017 mengenai Penguatan Pendidikan Karakter (PPK) menjadikan pendidikan karakter sebagai platform pendidikan nasional untuk membekali peserta didik sebagai generasi emas tahun 2045 dengan jiwa Pancasila, dan karakter yang baik dalam menghadapi dinamika perubahan dimasa depan (pasal 2).

Menurut Kesuma (2012) bahwa karakter berasal dari nilai sesuatu, nilai yang diwujudkan dalam sebuah bentuk perilaku, perilaku baik maupun buruk anak itulah yang dimaksud dengan karakter. Nilai karakter telah melekat pada setiap individu, setiap individu memiliki karakteristik psikologis yang berbeda-beda. Menurut Hadisi (2015) bahwa nilai-nilai pendidikan karakter yang dikembangkan dalam bentuk pendidikan karakter yang bersumber dari agama, Pancasila, budaya dan tujuan pendidikan nasional Indonesia. Berdasarkan empat sumber nilai tersebut, terdapat 18 nilainilai karakter untuk pendidikan budaya dan karakter bangsa, namun pada modul ini terdapat 4 nilai karakter yaitu nilai karakter disiplin, jujur, peduli lingkungan, dan rasa ingin tahu. Selain itu modul juga dilengkapi dengan gambar-gambar sebagai penunjang materi.

Modul ini dilengkapi gambar yang mendukung dari isi materi, karena gambar lebih menarik perhatian pembaca khususnya peserta didik. Menurut Sari dan Sutarto (2017) bahwa gambar adalah alat visual penting karena dapat memberikan penggambaran visual yang bersifat konkret mengenai masalah yang digambarkan. Gambar juga dapat memfokuskan perhatian dari peserta didik pada masalah tertentu, hal ini dapat membantu peserta didik mengingat lebih banyak konsep, sehingga perlu ditambahkan lebih banyak gambar-gambar yang berkaitan dengan materi yang terdapat dalam modul. Modul menampilkan gambar-gambar yang berkaitan dengan materi pembelajaran, umumnya peserta didik akan lebih tertarik dengan gambar-gambar dibandingkan dengan banyaknya tulisan, karena terdapat banyak gambar-gambar, dimana gambar tersebut didapatkan tidak dari 
dokumentasi pribadi maka mengenai sumbersumber gambar atau artikel menggunakan sumber yang lebih konkret, tidak menggunakan sumber yang bersifat umum. Menurut Amien (2018) bahwa untuk berhati-hati dalam mengutip agar terhindar dalam tindakan kegiatan plagiat, maka diperlukan mencantumkan sumber-sumber dengan baik agar menghindari terjadinya plagiat. Selain dari gambar-gambar, ukuran, serta margin juga perlu diperhatikan agar bentuk dari modul menjadi menarik.

Penggunaan margin dan ukuran tulisan dalam modul perlu diperhatikan, margin dan ukuran tulisan menyesuaikan dengan ukuran modul untuk keindahan dan kerapihan dari sebuah modul. Menurut Ramadhani dan Mahardika (2015) bahwa modul merupakan salah satu bentuk bahan ajar yang memiliki tujuan dalam menciptakan pembelajaran yang menarik, efektif, efisien, dan menyenangkan, agar modul tersebut dapat menarik bagi peserta didik sehingga dapat meningkatkan minat, dan motivasi belajar, sehingga dalam mengembangkan sebuah modul sebaiknya memperhatikan aspek kegrafikaannya, aspek kegrafikaan meliputi ukuran atau format modul , desain bagian luar, desain dan bagian isi. Menurut Anggoro (2015) bahwa pada proses pembelajaran menggunakan modul, peserta didik dituntut untuk belajar secara mandiri, dan mampu memecahkan masalah dengan cara mengeluarkan ide-idenya, sehingga desain modul diperhatikan sedemikian rupa untuk peserta didik lebih mudah dalam memahami isi materi, dan peserta didik tertarik dalam membaca isi modul.

Menurut Fathonah (2016) bahwa membaca adalah salah satu bentuk kegiatan untuk memahami isi bacaan sehingga penulisan kalimat pada modul ini menggunakan Bahasa peneliti untuk memudahkan pemahaman peserta didik dalam pembelajaran, dengan memperhatikan penulisan kalimat pada materi yang terdapat dalam modul berdasarkan Bahasa Indonesia yang baku serta tidak berbelit-belit. Menurut Setiawati (2016) bahwa kata baku merupakan kata yang lazim digunakan pada situasi formal atau resmi yang ditulis sesuai dengan kaidah-kaidah yang dibakukan, kata baku digunakan pada pengembangan modul ini agar pembaca khususnya peserta didik mampu memahami materi dengan baik, dan padat.
Pembelajaran dengan menggunakan bahan ajar berupa modul ini juga tidak lepas dari peran guru, tetapi peran guru hanya mengarahkan kepada peserta didik, dari kegiatan yang dilakukan peserta didik, guru dapat melihat seberapa jauh peserta didik mampu berpikir kreatif dalam memecahkan masalah pada soal. Produk berupa modul ini memiliki beberapa komponen-komponen, komponen pada modul menurut Parmin (2012) menyatakan bahwa komponen-komponen modul mencakup pendahuluan, kegiatan belajar, dan daftar pustaka. Berdasarkan sumber tersebut, peneliti menambahkan komponen-komponen lainnya agar modul menjadi lebih lengkap antara lain, bagian awal terdiri dari judul atau halaman sampul; kata pengantar; daftar isi; Kompetensi Inti (KI); Kompetensi Dasar (KD); Indikator Pencapaian Kompetensi (IPK), penggunaan simbol pada Indikator Pencapaian Kompetensi (IPK) menggunakan numbering mengikuti Kompetensi Dasar (KD) yang telah ditetapkan, tidak menggunakan simbol-simbol untuk menandainya, karena indikator tersebut di buat sesuai dengai Kompetensi Dasar yang telah ditetapkan agar terlihat lebih jelas; tujuan pembelajaran; petunjuk penggunaan modul; alokasi waktu; dan peta konsep. Bagian inti yang terdiri atas pendahuluan, uraian materi, Lembar Kegiatan Peserta Didik (LKPD), rangkuman, umpan balik dan uji kompetensi. Bagian penutup terdiri dari, glosarium, daftar pustaka, dan kunci jawaban. Komponen bagian awal modul terdapat cover atau halaman sampul yang berperan penting dalam modul.

Sampul modul atau cover di desain sedemikian rupa agar mencakup isi dari modul, dan di desain maksimal agar sampul terlihat menarik bagi pembaca, serta peletakkan gambar-gambar, tulisan diperhatikan untuk kerapihan dari tampilan sampul, dalam bagian inti modul terdapat pula Lembar Kegiatan Peserta Didik (LKPD). Lembar Kegiatan Peserta Didik (LKPD) menyediakan kolom untuk peserta didik dapat langsung menjawab soal-soal kegiatan yang terdapat di dalam modul, karena modul adalah bahan ajar yang dapat dipelajari peserta didik secara mandiri. Menurut Aditia dan Muspiroh (2013) bahwa modul yaitu alat atau sarana kegiatan pembelajaran yang berisi materi, metode, batasan materi pembelajaran, petunjuk belajar, dan latihan secara menarik dan sistematis agar 
tercapai tujuan yang diharapkan, serta dilakukan secara mandiri.

Berikut beberapa perbaikan yang telah dilaksanakan dalam pengembangan modul ini yaitu:

1. Perbaikan gambar pada modul.

Sebelum direvisi terdapat materi yang tidak dilengkapi dengan gambar, perbaikan yang dilakukan yaitu menambahkan gambar-gambar yang berkaitan dengan materi agar peserta didik lebih tertarik untuk membaca.

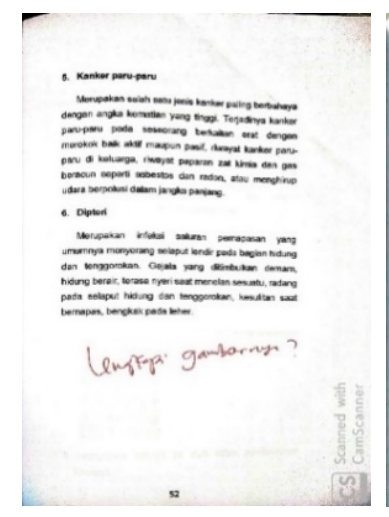

(a)

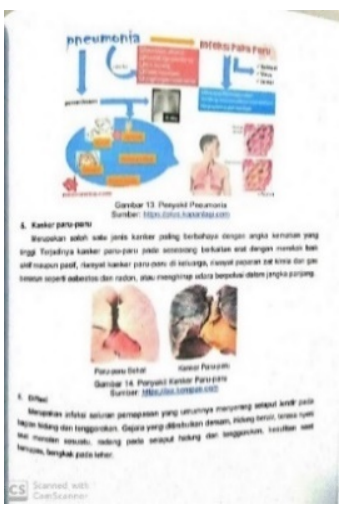

(b)
Gambar 2. (a) Isi Modul Sebelum Diperbaiki, (b) Isi Modul Setelah Diperbaiki.

2. Perbaikan margin pada modul.

Sebelum direvisi margin pada modul terlalu besar kurang menyesuaikan ukuran modul, setelah dilakukan perbaikan margin menyesuaikan ukuran modul agar modul terlihat lebih rapi.

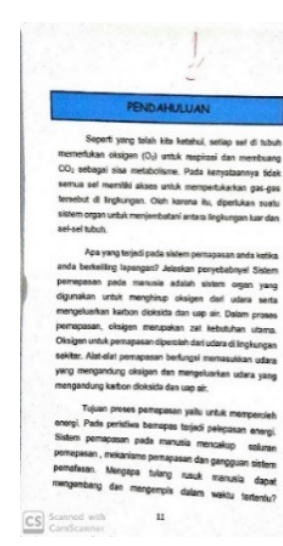

(a)

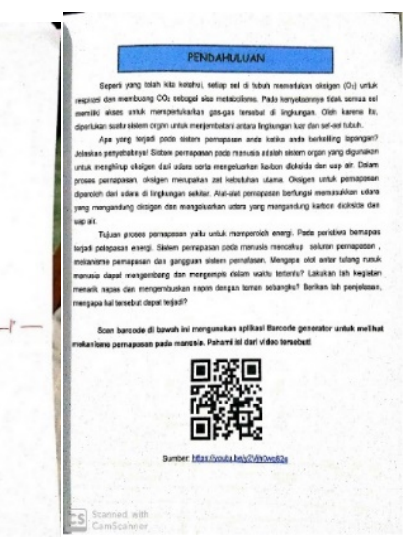

(b)
Gambar 3. (a) Margin Sebelum Diperbaiki, (b) Margin Setelah Diperbaiki.
3. Perbaikan ukuran tulisan (font).

Sebelum dilakukan perbaikan ukuran tulisan pada modul terlalu besar yaitu menggunakan Arial 11, setelah diperbaiki ukuran tulisan diperkecil dengan menggunakan Arial 10 agar terlihat lebih seimbang antara ukuran modul dan ukuran tulisan.

\section{Perbaikan tata letak logo pada cover.}

Sebelum diperbaiki letak logo UM Metro pada bagian bawah kiri pada cover, setelah diperbaiki tata letak logo tersebut diletakkan di bagian atas kanan pada cover agar sejajar dengan logo Tut Wuri Handayani.

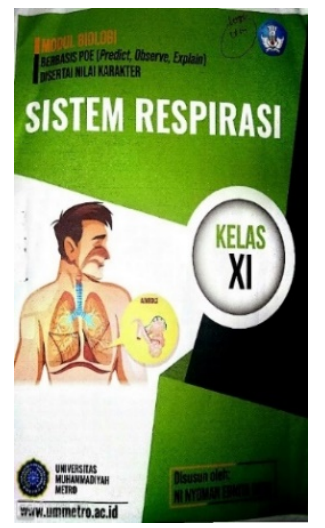

(a)

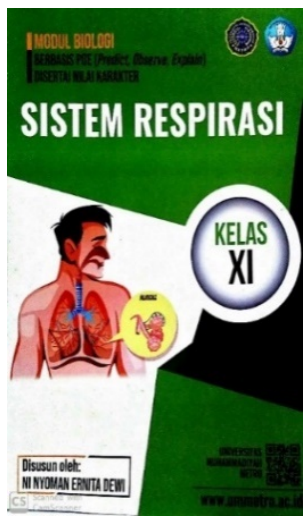

(b)
Gambar 4. (a) Cover Sebelum Diperbaiki, (b) Cover Sesudah Diperbaiki.

5. Perbaikan penulisan indikator pada modul. Sebelum diperbaiki, indikator di tandai dengan menggunakan symbol, setelah dilakukan perbaikan indikator menggunakan numbering agar terlihat lebih jelas.

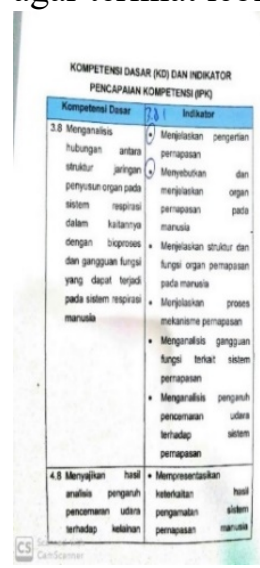

(a)

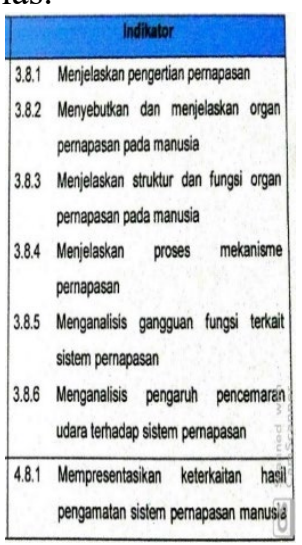

(b)
Gambar 5. (a) Indikator Sebelum Diperbaiki, (b) Indikator Setelah Diperbaiki. 


\section{SIMPULAN}

Berdasarkan penjelasan yang telah dijelaskan di atas mengenai pengembangan modul biologi metode POE (Predict, Observe, Explain) disertai nilai karakter materi sistem respirasi yang telah diujicobakan menunjukkan bahwa kelayakan dan keterbacaan produk ini dikatagorikan "sangat baik" dengan persentase nilai dari ahli desain $86 \%$, ahli materi $90 \%$, dan uji coba kelompok kecil dengan persentase $86 \%$. Hal ini menunjukkan bahwa modul topik sistem respirasi dengan metode POE yang bermuatan karakter dapat digunakan oleh guru pada saat memfasilitasi siswa.

\section{UCAPAN TERIMA KASIH}

Penulis mengucapkan terimakasih kepada dosen pembimbing, orang tua, dan teman-teman seperjuangan yang selalu mendukung usaha penulis.

\section{REFERENSI}

Aditia, M. T. dan Muspiroh, N. 2013. Pengembangan Modul Pembelajaran Berbasis Sains, Lingkungan, Teknologi, Masyarakat, dan Islam (Salingtemasis) dalam Meningkatkan Hasil Belajar Siswa pada Konsep Ekosistem Kelas X Di SMA NU (Nadhatul Ulama) Lemahabang Kabupaten Cirebon. Jurnal Scientiae Educatia. 2(2). 7-8.

Amien, J. A. 2018. Pelatihan Cara Teknik Pengutipan dan Cara Menghindari Tindakan Plagiat Bagi Para Guru SMK Muhammadiyah 3 Pekanbaru. Jurnal Pengabdian Untuk Mu NegeRI. 2(2). 42.

Anggoro, B. S. 2015. Pengembangan Modul Matematika dengan Strategi Problem Solving untuk Mengukur Tingkat Kemampuan Berpikir Kreatif Matematis Siswa. Jurnal Pendidikan Matematika. 6(2). 124.

Ariyanti, L. Utami, B. dan VH, E. S. 2018. Penerapan Model Pembelajaran Predict Observe Explain (POE) dilengkapi LKS Berbasis Drill and Practice untuk Meningkatkan Keaktifan dan Prestasi Belajar Siswa pada Materi Hidrolisis Garam Kelas XI IPA 3 Semester genap SMA N 2 Karanganyar Tahun Pelajaran 2016/2017. Jurnal Pendidikan Kimia. 7(1). 87.
Ayu, Y. P. dan Lepiyanto, A. 2019. Pengembangan Modul Berbasis POE (Predict Observe Explain) Terintegrasi Nilai Keislaman Materi Jaringan Tumbuhan. Jurnal Bioterdidik. 7(4). 55.

Fathonah, F. S. 2016. Penerapan Model POE (Predict-Observe-Explain) untuk Meningkatkan Keterampilan Membaca Pemahaman Siswa Kelas IV Sekolah Dasar. Jurnal Pendidikan Guru Sekolah Dasar. 1(1). 173.

Hadisi, L. 2015. Pendidikan Karakter pada Anak Usia Dini. Jurnal Al-Ta'dib. 8(2). 56-57.

Herdianawati, S. Fitrihidajati, H. dan Purnomo, T. 2013. Pengembangan Lembar Kegiatan Siswa (LKS) Inkuiri Berbasis Berpikir Kritis pada Materi Daur Biogeokimia Kelas X. Jurnal BioEdu. 2(1). 100 .

Hidayah, N. 2015. Penanaman Nilai-Nilai Karakter dalam Pembelajaran Bahasa Indonesia di Sekolah Dasar. Jurnal Pendidikan dan Pembelajaran Dasar. 2(2). 194.

Kesuma, D. Triatna, C. dan Permana, J. 2012. Pendidikan Karakter (Kajian Teori dan Praktik di Sekolah). Cetakan Ketiga. PT Remaja Rosdakarya Offset. Bandung.

Megayani. 2017. Penerapan Strategi PredictObserve-Explain (POE) Untuk Meningkatkan Hasil Belajar Siswa pada Pokok Bahasan Pencemaran Lingkungan Di Kelas VII SMP Negeri 2 Sumber Kabupaten Cirebon. Jurnal Bio Education. 2(1). 59.

Nugraha, D. A. 2019. Meta Analisis Pengaruh Model Pembelajaran POE terhadap Pemahaman Konsep. Jurnal Seminar Nasional Fisika dan Aplikasinya. ISSN: 2548-8325. 174.

Parmin. 2012. Pengembangan Modul Pembelajaran IPA Terpadu Berwawasan Sains, Lingkungan, Teknologi Dan Masyarakat. Jurnal Penelitian Pendidikan. 29(2). 129.

Ramadhani, W. P. dan Mahardika, I. K. 2015. Kegrafikaan Modul Pembelajaran Fisika Berbasis Multirepresentasi. Jurnal Seminar Nasional Fisika dan Pembelajaran. ISBN: 978-602-71279-19. 86. 
Ramdani, Yani. 2012. Pengembangan Instrumen dan Bahan Ajar untuk Meningktkan Kemampuan Komunikasi, Penalaran, dan Koneksi Matematis dalam Konsep Integral. Jurnal Penelitian Pendidikan. 13(1). 46.

Richardo, Rino. 2016. Peran Ethnomatematika dalam Penerapan Pembelajaran Matematika pada Kurikulum 2013. Jurnal Literasi. 7(2). 118.

Riduwan. dan Akdon. 2015. Rumus dan Data Dalam Analisis Statistika Untuk Penelitian (Administrasi PendidikanBisnis-Pemerintahan-Sosial-KebijakanEkonomi-Hukum-Manajemen-

Kesehatan). Cetakan keenam. Alfabeta. Bandung.

Sari, N. T. dan Sutarto. S. 2017. Pengembangan Modul Berbasis Gambar Kejadian Riil Untuk Pembelajaran Fisika SMA. Jurnal Pembelajaran Fisika. 6(1). 9-10.

Sayektiningsih. Samardjoko, B. dan Muhibin, A. 2017. Penanaman Nilai-Nilai Karakter dalam Pembelajaran Pendidikan Pancasila dan Kewarganegaraan di Madrasah Aliyah Muhammadiyah Klaten. Jurnal Managemen Pendidikan. 12(2). 229-230.

Setiawati, S. 2016. Penggunaan Kamus Besar Bahasa Indonesia (KBBI) dalam Pembelajaran Kosakata Baku dan Tidak Baku Pada Siswa Kelas IV SD. Jurnal Gramatika. ISSN:2442-8485. 48.

Widyaningrum, Ratna. Sarwanto. dan Karyanto, Puguh. 2013. Pengembangan Modul Berorientasi POE (Predict, Observe, Explain) Berwawasan Lingkungan Pada Materi Pencemaran Untuk Meningkatkan Hasil Belajar Siswa. Jurnal Bioedukasi. 6(1). 103. 